\title{
MORPHOMETRIC STUDY OF LOWER END OF DRY FEMUR IN GUJARAT REGION AND ITS CLINICAL IMPLICATION
}

\author{
Ankur Z Zalawadia ${ }^{1}$, Dhara H Parekh *2, Shailesh M Patel ${ }^{3}$. \\ ${ }^{1}$ Associate Professor, Dept. of Anatomy, Govt. Medical College, Bhavnagar, Gujarat, India. \\ ${ }^{* 2}$ Assistant Professor, Dept. of Anatomy, Govt. Medical College, Bhavnagar, Gujarat, India. \\ ${ }^{3}$ Professor and Head, Dept. of Anatomy, Govt. Medical College, Bhavnagar, Gujarat, India.
}

\section{ABSTRACT}

Introduction: Lower end of femur is major component of knee joint. Accurate morphometric anatomical data of the lower end of femur and gender morphometric differences are very important to make design of total knee joint replacement and internal fixation material. Knee prosthesis made based on morphometric data of components of knee (femur and tibia) and according to gender will give better results in early mobility as well as fewer complications.

Aim: Present study was done to find out sexual dimorphism in lower end of femur as well as differences between morphometric data of lower end of femur between other populations of world and within India.

Materials and Methods: For the present study the material consisted of 120 dry femur of known gender were used. Out of them 60 were of male ( 30 of right side and 30 of left side) and 60 were of female (30 of right side and 30 of left side). We have selected six metrical parameters 1 . Bicondylar width (BCW), 2. Medial condylar anteroposterior distance (MCAPD), 3. Lateral condylar antero-posterior distance (LCAPD), 4. Medial condylar transverse distance (MCTD), 5. Lateral condylar transverse distance (LCTD) and 6. Intercondylar notch width (ICW) for the present study based on which the prosthesis for knee joint replacement surgery is made.

Results: All six parameters which are chosen are found significantly larger in male than females. The findings are smaller than Caucasian population and found larger than other population of Andhra Pradesh and West Bengal.

Conclusion: Present study provides data of measurement of lower end of femur by direct observation which will be useful to select correct prosthesis according to measurements. We have also provided data for gender wise and on right and left side which will improve the longitivity of prosthesis, increased mobility and lifestyle of patient after knee replacement surgery.

KEY WORDS: Dry Femur, Lower End, Morphometry, Knee Prosthesis.

Address for Correspondence: Dr. Dhara H Parekh, B-303, Leela Shanti Heights, Iscon Mega City, Opp. Victoria Park, Bhavnagar-364002, Gujarat, India. Mo. No.: +919428009961

E-Mail: pulkitdhara@gmail.com

\section{Access this Article online}

\section{Quick Response code}

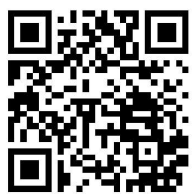

DOI: $10.16965 /$ ijar.2017.406

Web site: International Journal of Anatomy and Research ISSN 2321-4287

www.ijmhr.org/ijar.htm

Received: 10 Aug 2017

Peer Review: 10 Aug 2017

Revised: None
Accepted: 03 Oct 2017

Published (O): 01 Nov 2017

Published (P): 01 Nov 2017

\section{INTRODUCTION}

Femur is the largest and longest bone in the body. The distal end of the femur is widely expanded, has two massive condyles - medial and lateral, and between condyles posteriorly there is intercondylar notch. The condyles of femur are partly articular and make joint inferiorly with corresponding condyles of tibia and anteriorly with patella [1].

There is increased need of total knee replacement (TKR) as there in increased incidence of 
osteoarthritis in increased incidence of obesity and rapidly aging population. Joint replacement has considered beneficial for removing pain and improve the lifestyle of patients in severe case of osteoarthritis [2].

Accurate morphometric anatomical data of the lower end of femur and gender morphometric differences are very important to make design of total knee joint replacement and internal fixation material $[3,4]$. Mismatch between Morphometric data and selected prosthesis may cause severe complications like anterior cruciate ligament rupture, soft tissue imbalance, decreased movements of knee and implant loosening. [3,59] So knee prosthesis made based on morphometric data of components of knee (femur and tibia) and according to gender will give better results in early mobility as well as less complications $[2,4]$.

Recent studies are based on difference between gender and ethnic groups. [3,4,10-13] Most of the morphometric studies are done with measurement by radiographs, CT scans or Magnetic resonance imaging techniques $[2,4,10-15]$. There are few data available in which the study is done over dry femur by direct observations $[3,16,17]$. We have done morphometric study of lower end of dry femur and in known gender. The results will give basic data and exact measurements of lower end of femur gender wise and of India population especially the eastern part before the knee replacement surgeries done over it.

\section{MATERIALS AND METHODS}

For study the material consisted of 120 dry femur of known gender were used. Out of them 60 were of male ( 30 of right side and 30 of left side) and 60 were of female (30 of right side and 30 of left side). Gender was assessed through the records available in Department of Anatomy, Government Medical College, Bhavnagar, Gujarat, India. All bones were on gross examination were fully ossified, had no evidence of fracture or any pathological or congenital anomalies. Damaged or bones with arthritic changes were excluded from the study. The study was done at Department of Anatomy, Government Medical College, Bhavnagar, Gujarat, India. The collected bones were

assessed with sliding caliper (Martin type, 0-200 $\mathrm{mm}$ ). The parameters which were measured are as follows:

Bicondylar width (BCW): The maximum distance across femoral condyles in transverse plane (Figure-1)

Medial condylar antero-posterior distance (MCAPD): The maximum anteroposterior distance of medial femoral condyle (Figure-2)

Lateral condylar antero-posterior distance (LCAPD): The maximum anteroposterior distance of lateral femoral condyle (Figure-3)

Medial condylar transverse distance (MCTD): The maximum transverse distance of medial femoral condyle (Figure-4)

Lateral condylar transverse distance (LCTD): The maximum transverse distance of lateral femoral condyle (Figure-5)

Intercondylar notch width (ICW): The maximum distance of intercondylar notch between two condyles posteriorly (Figure-6)

The above data obtained and statistically analysed.

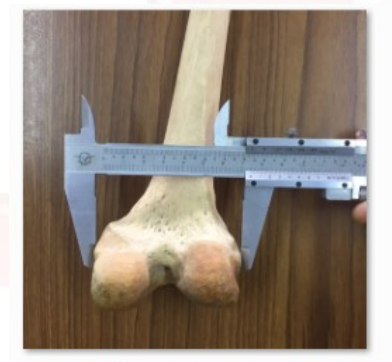

Figure 1 Measurement of bicondylar width (BCW)

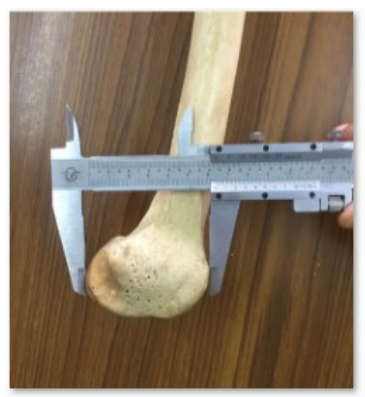

Figure 3 Measurement of lateral condylar antero-posterior distance (LCAPD)

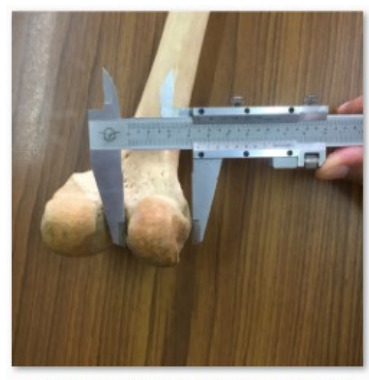

Figure 5 Measurement of lateral condylar transverse distance (LCTD)

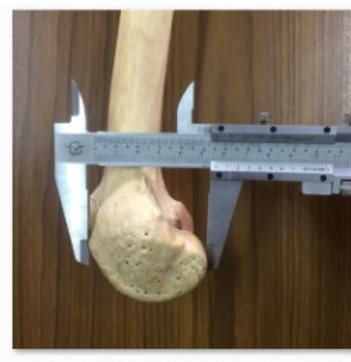

Figure 2 Measurement of medial condylar antero-posterior distance (MCAPD)

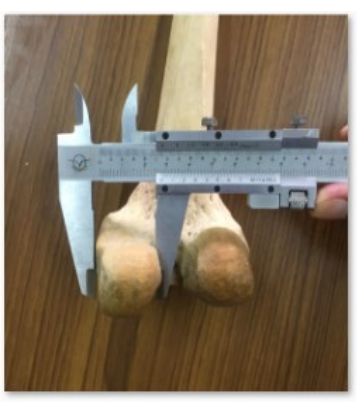

Figure 4 Measurement of medial condylar transverse distance (MCTD)

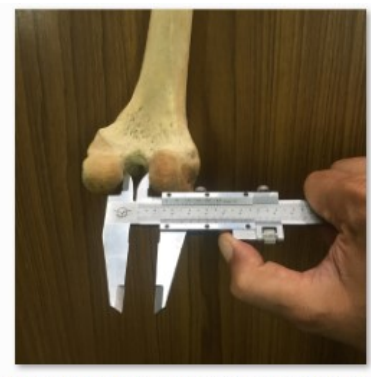

Figure 6 Measurement Intercondylar notch width (ICW) 
The morphometric measurements of the lower end of the femur are summarized in Table 1.

Table 1: Measurements of lower end of the femur in $\mathrm{mm}$.

\begin{tabular}{|c|c|c|c|c|c|c|}
\hline Parameters & Side & $\begin{array}{c}\text { Male } \\
\text { (Mean士SD) }\end{array}$ & $\begin{array}{c}\text { Combined } \\
\text { (Male) } \\
\text { (Mean } \pm \text { SD) }\end{array}$ & $\begin{array}{c}\text { Female } \\
\text { (Mean } \pm S D)\end{array}$ & $\begin{array}{c}\text { Combined } \\
\text { (Female) } \\
\text { (Mean } \pm \text { SD) }\end{array}$ & p-Value* \\
\hline \multirow{2}{*}{ BCW } & Right & $74.48 \pm 1.90$ & \multirow{2}{*}{$74.53 \pm 2.34$} & $67.42 \pm 1.93$ & \multirow{2}{*}{$67.09 \pm 2.11$} & \multirow{2}{*}{$<0.05$} \\
\hline & Left & $74.59 \pm 2.75$ & & $66.75 \pm 2.59$ & & \\
\hline \multirow{2}{*}{ MCAPD } & Right & $57.21 \pm 2.53$ & \multirow{2}{*}{$57.49 \pm 2.34$} & $53.44 \pm 1.82$ & \multirow{2}{*}{$53.91 \pm 2.05$} & \multirow{2}{*}{$<0.01$} \\
\hline & Left & $57.77 \pm 2.15$ & & $54.37 \pm 2.20$ & & \\
\hline \multirow{2}{*}{ LCAPD } & Right & $58.36 \pm 3.03$ & \multirow{2}{*}{$59.02 \pm 2.69$} & $54.98 \pm 1.89$ & \multirow{2}{*}{$54.82 \pm 2.34$} & \multirow{2}{*}{$<0.05$} \\
\hline & Left & $59.68 \pm 2.16$ & & $54.66 \pm 2.87$ & & \\
\hline \multirow{2}{*}{ MCTD } & Right & $30.31 \pm 1.66$ & \multirow{2}{*}{$30.32 \pm 3.88$} & $27.47 \pm 1.33$ & \multirow{2}{*}{$27.69 \pm 1.43$} & \multirow{2}{*}{$<0.05$} \\
\hline & Left & $31.32 \pm 1.35$ & & $27.91 \pm 1.52$ & & \\
\hline \multirow{2}{*}{ LCTD } & Right & $31.32 \pm 1.72$ & \multirow{2}{*}{$31.65 \pm 1.49$} & $28.76 \pm 1.47$ & \multirow{2}{*}{$28.88 \pm 1.39$} & \multirow{2}{*}{$<0.01$} \\
\hline & Left & $31.99 \pm 1.15$ & & $28.96 \pm 1.33$ & & \\
\hline \multirow{2}{*}{ ICW } & Right & $20.31 \pm 2.94$ & \multirow{2}{*}{$21.11 \pm 2.02$} & $19.42 \pm 2.32$ & \multirow{2}{*}{$19.35 \pm 2.52$} & \multirow{2}{*}{$<0.001$} \\
\hline & Left & $20.91 \pm 1.32$ & & $19.27 \pm 2.74$ & & \\
\hline
\end{tabular}

* The $p$-values are calculated for comparison across genders

According to Table 1 the mean bicondylar width $(B C W)$ in Gujarat region in males was $74.53 \pm 2.34$ $\mathrm{mm}(74.48 \pm 1.90 \mathrm{~mm}$ on right side and $74.59 \pm 2.75 \mathrm{~mm}$ on left side) while in females it was $67.09 \pm 2.11 \mathrm{~mm}(67.42 \pm 1.93 \mathrm{~mm}$ on right side and $66.75 \pm 2.59 \mathrm{~mm}$ on left side) $[p<0.05]$. The medial condylar anteroposterior distance (MCAPD) in males was $57.49 \pm 2.34 \mathrm{~mm}$ (57.21 $\pm 2.53 \mathrm{~mm}$ on right side and $57.77 \pm 2.15$ $\mathrm{mm}$ on left side) while in females it was $53.91 \pm 2.05(53.44 \pm 1.82 \mathrm{~mm}$ on right side and $54.37 \pm 2.20 \mathrm{~mm}$ on left side) $[p<0.01]$. The lateral condylar anteroposterior distance (LCAPD) in males was $59.02 \pm 2.69 \mathrm{~mm}(58.36 \pm 3.03 \mathrm{~mm}$ on right side and $59.68 \pm 2.16 \mathrm{~mm}$ on left side) while in females it was $54.82 \pm 2.34 \mathrm{~mm}(54.98 \pm 1.89$ $\mathrm{mm}$ on right side and $54.66 \pm 2.87 \mathrm{~mm}$ on left side) $[p<0.05]$. The medial condylar transverse distance (MCTD) in males was $30.32 \pm 3.88 \mathrm{~mm}$ $(30.31 \pm 1.66 \mathrm{~mm}$ on right side and $31.32 \pm 1.35$ $\mathrm{mm}$ on left side) while in females it was $27.69 \pm 1.43 \mathrm{~mm}(27.47 \pm 1.33 \mathrm{~mm}$ on right side and $27.91 \pm 1.52 \mathrm{~mm}$ on left side) $[p<0.05]$. The lateral condylar transverse distance (LCTD) in males was $31.65 \pm 1.49 \mathrm{~mm}(31.32 \pm 1.72 \mathrm{~mm}$ on right side and $31.99 \pm 1.15 \mathrm{~mm}$ on left side) while in females it was $28.88 \pm 1.39 \mathrm{~mm}(28.76 \pm 1.47$ $\mathrm{mm}$ on right side and $28.96 \pm 1.33 \mathrm{~mm}$ on left side) $[p<0.01]$. The intercondylar width (ICW) in males was $21.11 \pm 2.02 \mathrm{~mm}(20.31 \pm 2.94 \mathrm{~mm}$ on right side and $20.91 \pm 1.32 \mathrm{~mm}$ on left side) while in females it was $19.35 \pm 2.52 \mathrm{~mm}(19.42 \pm 2.32$ $\mathrm{mm}$ on right side and $19.27 \pm 2.74 \mathrm{~mm}$ on left side) $[p<0.001]$.

\section{DISCUSSION}

In this study we have selected six morphometric parameters of lower end of dry femur and data collected by using the sliding caliper by direct observation. Most of the morphometric studies are done with measurement by radiographs, CT scans or magnetic resonance imaging techniques which are indirect methods $[2,4,10-15]$. There are studies which suggest that indirect method of measurement are found inaccurate and not precise even though they are corrected by the projection method as well as by the resolutions. [2,17-19]. So direct method of measurement is beneficial over the indirect methods which gives the accurate morphometric data. Because the direct method of measurement is accurate we can match these morphometric data for making of prosthesis for joint replacement surgery with the resected surface of the knee that will improvement factor for long term success of prosthesis and less complications in total knee joint replacement.

There are several studies done which are based on western population and also the prosthesis available in market is based on western population $[9,11]$ although the Indians have smaller knees as compared to them. This study will provide data and will influence in the clinical outcome to design improved prosthesis based 
Table 2: Comparison of studies of various authors on morphometric study of lower end of femur (data in Mean \pm SD in $\mathrm{mm}$ ).

\begin{tabular}{|c|c|c|c|c|c|c|c|c|}
\hline Sr. No. & Author, year and method of study & Country and region & $\mathrm{BCW}$ & MCAPD & LCAPD & MCTD & LCTD & ICW \\
\hline \multirow{2}{*}{1} & \multirow{2}{*}{$\begin{array}{c}\begin{array}{c}\text { Magetsari R et al [2], 2015, CT } \\
\text { scan }\end{array} \\
\end{array}$} & Indonesia males & $70.56 \pm 5.17$ & $44.27 \pm 4.91$ & $43.30 \pm 6.75$ & & & \\
\hline & & Indonesia females & $61.40 \pm 4.01$ & $40.85 \pm 5.73$ & $40.95 \pm 5.17$ & & & \\
\hline \multirow{2}{*}{2} & \multirow{2}{*}{$\begin{array}{l}\text { Terzidis I et al [3], 2012, } \\
\text { dry femur }\end{array}$} & Greek males & $88.6 \pm 0.42$ & $61.1 \pm 0.34$ & $61.1 \pm 0.33$ & & & $22.0 \pm 0.18$ \\
\hline & & Greek females & $78.5 \pm 0.30$ & $55.9 \pm 0.29$ & $55.4 \pm 0.21$ & & & $18.7 \pm 0.10$ \\
\hline \multirow{2}{*}{3} & \multirow{2}{*}{$\begin{array}{l}\text { Cheng FB et al [4], 2009, } \\
\text { CT scan }\end{array}$} & Chinese males & $74.4 \pm 2.90$ & \multicolumn{2}{|c|}{$66.60 \pm 2.40$} & & & \\
\hline & & Chinese females & $66.8 \pm 3.11$ & \multicolumn{2}{|c|}{$61.0 \pm 2.46$} & & & \\
\hline \multirow{2}{*}{4} & \multirow{2}{*}{$\begin{array}{l}\text { Hussain F et al [14], 2013, } \\
\text { CT scan }\end{array}$} & Malaysian males & $74.91 \pm 3.52$ & \multicolumn{2}{|c|}{$64.02 \pm 3.38$} & & & \\
\hline & & Malaysian females & $64.53 \pm 3.07$ & \multicolumn{2}{|c|}{$57.33 \pm 3.26$} & & & \\
\hline \multirow{2}{*}{5} & \multirow{2}{*}{$\begin{array}{c}\text { Moghtadaei M et al [15], 2016, CT } \\
\text { scan }\end{array}$} & Iranian males & & & $63.35 \pm 3.1$ & $24.61 \pm 1.9$ & $24.42 \pm 2.0$ & $21.76 \pm 3.0$ \\
\hline & & Iranian females & & & $56.53 \pm 2.98$ & $21.33 \pm 0.2$ & $21.37 \pm 1.6$ & $17.37 \pm 2.5$ \\
\hline 6 & $\begin{array}{l}\text { Neelima P et al [16], 2016, } \\
\text { dry femur }\end{array}$ & India (Andhra Pradesh) & & $57.83 \pm 0.69$ & $58.0 \pm 0.51$ & $21.33 \pm 0.43$ & $21.08 \pm 0.44$ & $22.83 \pm 0.41$ \\
\hline \multirow{2}{*}{7} & \multirow{2}{*}{$\begin{array}{l}\text { Biswas A et al [17], 2017, } \\
\text { dry femur }\end{array}$} & India (West Bengal) Right side & $71.71 \pm 4.50$ & $52.97 \pm 3.77$ & $56.20 \pm 3.36$ & $25.48 \pm 2.05$ & $27.80 \pm 2.91$ & $20.86 \pm 2.52$ \\
\hline & & India (West Bengal) Left side & $70.71 \pm 5.25$ & $54.74 \pm 3.85$ & $56.05 \pm 4.29$ & $27.28 \pm 2.29$ & $28.03 \pm 2.56$ & $19.45 \pm 2.57$ \\
\hline \multirow{2}{*}{8} & \multirow{2}{*}{ Present study } & India (Gujarat) males & $74.53 \pm 2.34$ & $57.49 \pm 2.34$ & $59.02 \pm 2.69$ & $30.32 \pm 3.88$ & $31.65 \pm 1.49$ & $21.11 \pm 2.02$ \\
\hline & & India (Gujarat) females & $67.09 \pm 2.11$ & $53.91 \pm 2.05$ & $54.82 \pm 2.34$ & $27.69 \pm 1.43$ & $28.88 \pm 1.39$ & $19.35 \pm 2.52$ \\
\hline
\end{tabular}

on our knee measurements.

There is significant difference in morphometric data of the lower end of femur in various populations of countries across world as well as populations within India. (Table 2)

The bicondylar width in male was $74.53 \pm 2.34$ $\mathrm{mm}$ and in female was 67.09 \pm 2.11 which was significantly greater in male than females $(p<0.05)$. The measurements are very high in Greek (Caucasian) population in male as well as females. [3] These measurements were almost similar to other populations of Asia $[4,14]$ but higher than population of West Bengal [17] and Indonesia [2] .

The medial condylar anteroposterior distance (MCAPD) in males was $57.49 \pm 2.34 \mathrm{~mm}$ while in females it was $53.91 \pm 2.05)$ which was significantly higher in male than female $(p<0.01)$. The lateral condylar anteroposterior distance (LCAPD) in males was $59.02 \pm 2.69 \mathrm{~mm}$ while in females it was $54.82 \pm 2.34 \mathrm{~mm}$ which was significantly higher in male than female $(p<0.05)$.These measurements were lower than Greek (Caucasian) [3], Chinese [4] and Malasian [14] populations but higher than Indonesian population [2]. It is found similar to the population of Andhra Pradesh [16] but slightly higher in male and lower in females than population of West Bengal [17].

The medial condylar transverse distance (MCTD) in males was $30.32 \pm 3.88 \mathrm{~mm}$ while in females it was $27.69 \pm 1.43 \mathrm{~mm}$ which was significantly higher in male than female $(p<0.05)$. The lateral condylar transverse distance (LCTD) in males was $31.65 \pm 1.49 \mathrm{~mm}$ while in females it was $28.88 \pm 1.39 \mathrm{~mm}$ which was significantly higher in male than female $(p<0.01)$. These combined data of MCAPD and LCAPD were higher significantly than population of Andhra Pradesh [16] and Iran [15]. As compared the population of West Bengal [17] the there is much difference found in males while the females have similar measurements.

The intercondylar width (ICW) in males was $21.11 \pm 2.02 \mathrm{~mm}$ while in females it was $19.35 \pm 2.52 \mathrm{~mm}$ which was significantly higher in male than female $(p<0.001)$. There is not much difference in measurement data between population across globe and found highest in Andhra Pradesh.

\section{CONCLUSION}

Present study provides data of measurement of lower end of femur by direct observation which will be useful to select correct prosthesis according to measurements. We have also provided data for gender wise and on right and left sides which will improve the longitivity of prosthesis, will increase mobility and improve lifestyle of patient after knee replacement surgery. Females will definitely benefit from newly designed gender-specific prosthesis.

\section{Conflicts of Interests: None}




\section{REFERENCES}

[1]. Gray's Anatomy. The Anatomical Basis of clinical Practice. $39^{\text {th }}$ Edition, Elsevier Churchil Livingstone. 2005;1434-35.

[2]. Rahadyan Magetsari et al. Three dimensional morphometry of distal femur to design knee prosthesis for Indonesian population. Int J Morphol 2015;33(4):1255-60.

[3]. Terzidis I, Totlis T, Papathanasiou E, Sideridis A, Vlasis K, Natsis K. Gender and Side-to-Side Differences of Femoral Condyles Morphology: Osteometric Data from 360 Caucasian Dried Femori. Anatomy Research International. 2012 http://dx.doi.org/ $10.1155 / 2012 / 679658$.

[4]. Cheng FB et al. Three dimensional morphometry of the knee to design the total knee arthroplasty for Chinese population. Knee 2009;16(5):341-7.

[5]. Anderson AF, Dome DC, Gautam S, Awh MH, Rennirt GW. Correlation of anthropometric measurements, strength, anterior cruciate ligament size and intercondylar notch characteristics to sex differences in anterior cruciate ligament tear rates. American Journal of Sports Medicine, 2001; 29(1):58-66.

[6]. Lombardo S, Sethi PM, StarkeyC. Intercondylar notch stenosis is not a risk factor for anterior cruciate ligament tears in professional male basketball players: an 11-year prospective study. American Journal of Sports Medicine 2005;33(1):29-34.

[7]. Murshed KA, Cicekcibasi AE, Karabacakoglu A, Seker M, Ziylan T. Distal femur morphometry: a gender and bilateral comparative study using magnetic resonance imaging. Surgical and Radiologic Anatomy 2005;27(2):108-112.

[8]. Insall J. Surgical techniques and instrumentation in total knee arthroplasty. $5^{\text {th }}$ Edition, New York:Churchill Livingstone. 2012;717-22.

[9]. Shahi AS et al. Special Considerations in Asian Knee Arthroplasty. INTECH Open Access Publisher;2013.

[10]. Urabe K, Mahoney OM, Mabuchi K, Itoman M. Morphologic differences of the distal femur between Caucasian and Japanese women. Journal of Orthopaedic Surgery 2008;16(3):312-315.

[11]. Yue B, Varadarajan KM, Ai S, Tang T, Rubash HE, Li G. Gender differences in the knees of Chinese population. Knee Surgery, Sports Traumatology, Arthroscopy $2011 ; 19(1): 80-88$.
[12]. Yazar F, Imre N, Battal B, Bilgic B, Tayfun C. Is there any relation between distal parameters of the femur and its height and width? Surgical and Radiologic Anatomy 2011;34(2):125-132.

[13]. Chin PL, Tey TT, Ibrahim MB, Chia SL, Yeo SJ, Lo NN. Intraoperative morphometric study of sex differences in Asian femurs. Journal of Arthroplasty 2011;26(7):984-988.

[14]. Hussain F, Kadir Md RA, Zulkifly AH, Sa'at A, Aziz AA, Hossain Md. G, Kamarul T, Syahrom A. Anthropometric Measurements of the Human Distal Femur: A Study of the Adult Malay Population. Biomed Research International Published online 2013 November 5. doi:10.1155/2013/175056

[15]. Moghtadaei M, Moghimi J, Shahhoseini G. Distal Femur Morphology of Iranian Population and Correlation With Current Prostheses. Iran Red Crescent Med J 2016;18(2): e21818. Published online 2016 Jan 6. doi: 10.5812/ircmj.21818

[16]. Neelima P, Ravisunder R, Himabindu A. A study on morphometric measurements of adult dried femora in Visakhapatanam. Int J Adv Res 2016;4(8):564567.

[17]. Biswas A, Bhattacharya S. A morphometric and radiological study of the distal end of femur in West Bengal population. Italian Journal of Anatomy and Embryology 2017;122(1): 39-48.

[18]. Horsman A, Leung WK, Bentley HB,. McLachlan MF. Effect of rotation on radiographic dimensions of the humerus and femur. British Journal of Radiology 1977;50(589):23-28.

[19]. Anderson AF, Anderson CN, Gorman TM, Cross MB, Spindler KP. Radiographic measurements of the intercondylar notch: are they accurate?" Arthroscopy 2007;23(3):261-268.

How to cite this article:

Ankur Z Zalawadia, Dhara H Parekh, Shailesh M Patel. MORPHOMETRIC STUDY OF LOWER END OF DRY FEMUR IN GUJARAT REGION AND ITS CLINICAL IMPLICATION. Int J Anat Res 2017;5(4.2):4595-4599. DOI: 10.16965/ijar.2017.406 